\title{
The Formulation of Lotion Preparations of Betel Leaf Extract (Piper betle)
}

Ingenida Hadning*, Putri Kurnyaningtyas, Muhammad Thesa Ghozali

School of Pharmacy, Faculty of Medicine and Health Science, Universitas Muhammadiyah Yogyakarta, Jl Brawijaya, Tamantirto, Kasihan, Bantul, Yogyakarta 55183.

\begin{abstract}
Betel leaf (Piper betle) contains an essential oil that has extreme antiseptic power (bactericidal and fungicidal). Betel leaf (Piper betle) can be used in the treatment of Tinea versicolor or known in the community as panu. However, its use in the form of leaves is considered impractical by the public and also difficult to obtain. This research formulated betel leaf (Piper betle) into lotion preparations, so its use in the community can be more practical. This study aims to determine the type and concentration of the suspending agent used to produce lotion preparations from betel leaf extract (Piper betle), which has optimal physical quality. This research was an experimental study. The distillation of betel leaf (Piper betle) was carried out to get essential oils. The essential oils of betel leaf (Piper betle), which was used as an active substance in formulations, was $5 \%$. Suspending agents that were used in this study were Arabic gum with concentrations of $10 \%, 15 \%, 20 \%$, and CMC Na, with concentrations of $0.25 \%, 0.5 \%$, and $1 \%$. The formulation of lotion preparations included organoleptic observation, $\mathrm{pH}$ test, homogeneity test, and adhesion test. Based on the physical quality test of the lotion preparations that had been conducted, it can be concluded that the lotion preparations of betel leaf extract with $20 \%$ concentration of Arabic Gum suspending agent had physical qualities in accordance with lotion dosage criteria.
\end{abstract}

Keywords: betel leaf extract; formulation; lotion; Piper betle

\section{Data of article}

Received : 28 Feb 2020

Reviewed : 9 May 2020

Accepted : 23 Jul 2020

DOI

10.18196/jfaps.010104

Type of article:

Research

\footnotetext{
*Corresponding author, e-mail: ingenida.hadning@umy.ac.id
} 


\section{INTRODUCTION}

Tinea versicolor is a non-inflammatory chronic disorder in which the type depends on the specific features, etiology, or place. Tinea versicolor is characterized by the presence of multiple macular spots that usually seen in the tropics area and caused by Malasseziafurfur. ${ }^{1}$ Tinea versicolor is a disease caused by a fungus that lodged in the skin, because the body neither maintained nor cleaned regularly. ${ }^{2}$ The community has known Tinea versicolor as Panu. Panu is a skin disease that often occurs, both in women and men, especially because it is associated with problems of hygiene and poor sanitation. The prevalence of Tinea versicolor $50 \%$ occurs in tropical communities, $5 \%$ in subtropical regions and $<1 \%$ in female populations $20.8 \%$ in the cold areas. 3

The public has long known the plant-based treatment. The effort to develop plants for treatment is required considering that in Indonesia, plants are easily obtained, and also at low prices. However, the use of plants for treatment needs to be supported by research data from these plants; thus, the efficacy is not scientifically doubtful, and it could be justified. It certainly can encourage the widespread use of the plants as medicine by the community. ${ }^{4}$

Piper betle is one of the medicinal plants that grows a lot in Indonesia and is known as Daun Sirih. Betel leaf is traditionally used as a mouth ulcer medicine, sore throat, cough medicine, eyewash medication, leucorrhoea, bleeding in the nose/nosebleeds, accelerate wound healing, eliminate bad breath, and treat toothache. Betel leaf has a typical aroma as it contains essential oils of $1-4.2 \%$, water protein, fat, carbohydrates, calcium, phosphorus, vitamins $A, B, C$ iodine, sugar, and starch. Based on these various contents, in essential oils, there are natural phenols which have extreme antiseptic power (bactericidal and fungicidal) but are not sporosid. 5,6

However, the use of medicinal plants in their original form is considered impractical and also challenging to obtain. Thus, in this study, betel leaf (Piper betle) has been formulated into a lotion preparation, so its use in the community can be more practical. This research aims to determine the type and concentration of suspending agent used to produce lotion preparations from betel leaf extract (Piper betle) which has optimal physical quality.

\section{METHODS}

This study is an experimental study. The research was conducted for one month at the Laboratory of Pharmacy Technology, Faculty of Medicine and Health Sciences, Muhammadiyah University of Yogyakarta.

\section{Materials}

The tools needed in this research were homogenizer ( $T 25$ digital Ultra-Turrax ${ }^{\circledR}$ ), $\mathrm{pH}$ meter (Mettler Toledo ${ }^{\circledR}$ ), and analytical balance (Mettler Toledo ${ }^{\circledR}$ ).

Meanwhile, the materials used in this study were betel leaf (Piper betle) obtained from Nasaran village, CangkrepLor, Purworejo District, Purworejo Regency, propylene glycol / PEG 400 (Brataco), CMC $\mathrm{Na}$ (Brataco), Arabic gum (Brataco), methylparaben/nipagin (Brataco), oleumrosae (Brataco), 70\% ethanol (Brataco) and aqua dest.

\section{Collection of Test Materials}

The betel leaves used in this study were obtained from the village of Narget, Cangkrep Lor, Purworejo District, Purworejo Regency. The betel leaves were 
fresh and free from pesticides and plant pests. They were separated from the stem and were washed with running water and cleaned from the dirt.

\section{Plant Determination}

The purpose of determination is to identify the correctness of the sample used in the study. Determination of betel leaf plants was carried out in the Division of Pharmaceutical Biology, Faculty of Pharmacy of Gadjah Mada University by matching the morphological characteristics that exist in the betel leaf plants against the literature of Flora of Java volume I. ${ }^{7}$

\section{Making Betel Leaf Extract (Piper betle)}

Six kilograms of fresh betel leaves were cut into pieces and put into cormorant filled with water. The distillation apparatus was then assembled with a cooler condenser. Sodium chloride was added to the distillate so that the emulsified oil was separated. The water phase was accommodated with Erlenmeyer. In the water phase, sodium chloride was added and separated by a separating funnel. This step was carried out repeatedly until all the oil was separated. In the oil phase obtained, anhydrous calcium chloride was added, decanted and weighed. ${ }^{8}$

Optimization of Lotion Base Formulation The process of producing lotion preparations in this study used six treatment formulas, such as Arabic gum $10 \%, 15 \%, 20 \%$, and CMC Na $0.25 \%, 0.5 \%$, $1 \%$, as shown in Table 1 . The producing process was that the betel leaves were separated from other ingredients. Suspending agent ingredients, such as Arabic gum and $\mathrm{CMC} \mathrm{Na}$, were developed first. The suspension material used was developed by producing the hydrocolloid dispersion stock and by sprinkling the CMC $\mathrm{Na} /$ Arabic gum powder slowly and little by little into a mortar that had been filled with hot water. After that, the CMC Na powder / Arabic gum was soaked, then stirred quickly.

Furthermore, the PEG 400 was poured, and then betel leaf extract was added. Methylparaben ingredient was dissolved using $70 \%$ ethanol. The $60 \mathrm{ml}$ of distilled water was then added into the components that had been slowly mixed while stirring. It was later put in a beaker glass. The stirring process was continued by using ultraturrax for 2 minutes.

Table 1. The Formula Development

\begin{tabular}{llllllll}
\hline $\begin{array}{l}\text { Name of Substance } \\
(\%)\end{array}$ & Function of Substance & G1 & $\mathbf{G}_{\mathbf{2}}$ & $\mathbf{G}_{\mathbf{3}}$ & $\mathbf{C}_{\mathbf{1}}$ & $\mathbf{C}_{\mathbf{2}}$ & $\mathbf{C}_{\mathbf{3}}$ \\
\hline Betel leaf extract & Active substance & 5 & 5 & 5 & 5 & 5 & 5 \\
Nipagin & Preervative & $\mathbf{1}$ & $\mathbf{1}$ & $\mathbf{1}$ & $\mathbf{1}$ & $\mathbf{1}$ & $\mathbf{1}$ \\
PEG 400 & Binder & 3 & 3 & 3 & 3 & 3 & 3 \\
CMC Na & Suspending agent & - & - & - & 0,25 & 0,5 & 1 \\
Arabic Gum & Suspending agent & 10 & 15 & 20 & - & - & - \\
Oleum Rose & Deodorizer & 1 & 1 & 1 & 1 & 1 & 1 \\
Aquadest & Solvent & ad 100 & ad 100 & ad 100 & ad 100 & ad 100 & ad 100 \\
\hline
\end{tabular}

\section{Note :}

G1: Lotion formulation with Arabic Gum 10\%

G2: Lotion formulation with Arabic Gum 15\%

G3: Lotion formulation with Arabic Gum 20\%

$\mathrm{C}_{1}$ : Lotion formulation with CMC Na $0.25 \%$

C2: Lotion formulation with CMC Na $0.5 \%$

$\mathrm{C}_{3}$ : Lotion formulation with CMC Na $1 \%$ 


\section{Selection of Lotion Formulations}

In this part, pH concentration measurements were taken for each lotion formula with a different betel leaf extract composition. The formula with the $\mathrm{pH}$ of the preparation must be consistent with the $\mathrm{pH}$ requirements of the antifungal lotion, which is 6.6-7.5. Formulations were made on a large scale, and evaluation was then carried out.

Physical Quality Test of Losio preparations Evaluation for lotion preparations was carried out to determine the stability of the preparation and the level of safety in pre-clinical use. The evaluation of lotion preparations included organoleptic observation, $\mathrm{pH}$ changes, homogeneity test, and adherence test. Organoleptic observation included observing changes in shape, color, and an odor that occurred at specific timescale for 28 days. The organoleptic observation was carried out on days $1,7,14$, and day $28.9 \mathrm{pH}$ measurements of the lotion formula that had been produced were carried out using a $\mathrm{pH}$ meter, and it was then dipped into lotion preparations. Upon the proper immersion process, the color change in the $\mathrm{pH}$ meter was observed and adjusted to the standard color on the device. Measurements were taken on days 1, 7, 14, 21 , and $28{ }^{10}$. The lotion homogeneity test was conducted by applying each formula sufficiently on a glass plate, then touched and rubbed. The mass of the lotion must show its homogeneous arrangement proved by the absence of solid material on the glass. The replication was carried out three times. Furthermore, the adhesive strength test was conducted using a glass object which was bound using two statives. One of the ends of the glass bonding object was given a 6o-gram ballast. Then, the resulting lotion was smeared on one of the glass objects and covered with another glass object and then suppressed with a weight of $1 \mathrm{~kg}$ for 5 minutes. The glass object was well positioned so that the two strings which bound the two glass objects stiffened up to release the ballast. Calculating the time was needed to take the two glass objects to release their attachment. ${ }^{7}$

\section{RESULTS AND DISCUSSION}

\section{Extraction}

Betel leaf extract was produced by taking fresh betel leaf essential oil and by referring to a study entitled Determination of Eugenol Levels in Essential Oils from Red Betel Leaves (Piper cf fragile Benth.) and Green Betel (Piper betle) by Gas Chromatography. ${ }^{8}$ Steam distillation method was chosen to take the betel leaf essential oil to be used as an active substance on the betel leaf lotion preparations. Betel leaf extract was made with $70 \%$ ethanol solvent. A total of $6 \mathrm{~kg}$ was used for the extraction process. Before the extraction process, betel leaves were chopped into $\pm 5 \mathrm{~cm}$, so that the essential oil contained in the betel leaf was easily produced. Then, the distillation process was carried out using water vapor for 6 hours with seven replications. It was intended that the betel leaf essential oil contained in the betel leaf could be extracted as a whole. After the distillation process was complete, the result of essential oils was produced. At first, the oil produced was murky yellow and still contained water. After adding anhydrous sodium sulfate to remove water in essential oils, clear yellow essential oils were obtained. Then essential oils that have been produced were used in this study.

\section{The Formulation of Lotion Preparations of Betel Leaf Extract}

The process of producing lotion preparations from betel leaf extract used 
three concentration ratios of a suspending agent of Arabic gum, which was 10\%, 15\%, 20\%. Meanwhile, CMC Na was $0.25 \%$, $0.5 \%, 1 \%$, and the concentration of betel leaf essential oil was 5\%.12. In addition, producing lotion preparations used PEG 400 as a binder. It has the advantages of being non-irritating, having good adhesion, and distribution to the skin and does not inhibit gas exchange and sweat production. Thus, it was easy to wash with water and can be used on hairy body parts. ${ }^{13}$ Moreover, in this study, Nipagin was used as a preservative as an antibacterial. ${ }^{14}$

Before being used in formulas, Arabic gum or CMC Na was developed. It aimed to thicken the viscosity of the liquid when the material was mixed. ${ }^{15}$ After the development of CMC Na was added, the betel leaf extract, which was an essential oil role was as the oil phase. After all the ingredients had been put into the mortar, Nipagin that had been dissolved with $70 \%$ ethanol was added. Then, the Aquadest was added up to $60 \mathrm{ml}$. After that, It was proceeded with the homogenization process using Ultraturrax to dissolve all the ingredients in the container evenly. After all the procedures were finished, the container should tightly be closed and stored at room temperature.

In the formulation of a lotion preparation, it is necessary to have certain ingredients to support the formation of the desired lotion. ${ }^{16}$ In this research, as a formula development, suspending agents were used, such as Arabic gum and CMC Na, with different concentration variations. In terms of Arabic gum, the concentration was $10 \%$, $15 \%$, $20 \%$, while CMC Na was $0.25 \%, 0.5 \%, 1 \%$. The suspending agents function to slow down deposition, prevent clumping of resin and fatty material. The process was by increasing the viscosity of the liquid.

\section{Physical Evaluation Results}

Organoleptic observations showed that the concentration of Arabic gum resulted in the form of betel leaf lotion. The concentration of Arabic gum on the formulation process of betel leaf lotion conducted for one month can be seen in table 2.

Table 2. The Organoleptic observation results

\begin{tabular}{|c|c|c|c|c|c|}
\hline \multirow{2}{*}{ Formula } & \multirow{2}{*}{ Description } & \multicolumn{4}{|c|}{ Organoleptic week- } \\
\hline & & 1 & 2 & 3 & 4 \\
\hline \multirow[t]{3}{*}{$\mathrm{G}_{1}$} & Shape & $C$ & C & C & $C$ \\
\hline & Color & $\mathrm{P}$ & $P$ & $P$ & $\mathrm{P}$ \\
\hline & Odor & ADS & ADS & ADS & ADS \\
\hline \multirow[t]{3}{*}{$\mathrm{G}_{2}$} & Shape & $C_{+}$ & $C_{+}$ & $C_{+}$ & $C_{+}$ \\
\hline & Color & $\mathrm{P}$ & $P$ & $\mathrm{P}$ & $\mathrm{P}$ \\
\hline & Odor & ADS & ADS & ADS & ADS \\
\hline \multirow[t]{3}{*}{$\mathrm{G}_{3}$} & Shape & K & K & K & K \\
\hline & Color & $P$ & $P$ & $P$ & $\mathrm{P}$ \\
\hline & Odor & $\mathrm{ADS}$ & $\mathrm{ADS}$ & ADS & ADS \\
\hline \multirow[t]{3}{*}{$C_{1}$} & Shape & $\mathrm{C}, \mathrm{Ks}$ & $\mathrm{C}, \mathrm{Ks}$ & $\mathrm{C}, \mathrm{Ks}$ & $\mathrm{C}, \mathrm{Ks}$ \\
\hline & Color & PK & PK & PK & PK \\
\hline & Odor & ADS & ADS & ADS & ADS \\
\hline \multirow[t]{3}{*}{$C_{2}$} & Shape & $\mathrm{C}+, \mathrm{Ks}$ & $\mathrm{C}+, \mathrm{Ks}$ & $\mathrm{C}+, \mathrm{Ks}$ & $\mathrm{C}+, \mathrm{Ks}$ \\
\hline & Color & PK & PK & PK & PK \\
\hline & Odor & ADS & ADS & ADS & ADS \\
\hline \multirow[t]{3}{*}{$C_{3}$} & Shape & $\mathrm{C}++, \mathrm{Ks}$ & $\mathrm{C}++, \mathrm{Ks}$ & $\mathrm{C}++, \mathrm{Ks}$ & $\mathrm{C}++, \mathrm{Ks}$ \\
\hline & Color & PK & PK & PK & PK \\
\hline & Odor & ADS & ADS & ADS & ADS \\
\hline \multicolumn{6}{|l|}{ Note: } \\
\hline $\begin{array}{l}\text { C } \\
\text { increase }\end{array}$ & \multicolumn{5}{|l|}{$\begin{array}{l}\text { : Liquid; + } \\
\text { ed viscosity }\end{array}$} \\
\hline Ks & \multicolumn{5}{|c|}{ : rough texture } \\
\hline K & \multicolumn{5}{|l|}{ : thick } \\
\hline$P$ & \multicolumn{5}{|l|}{ : white } \\
\hline PK & \multicolumn{5}{|c|}{ : yellowish-white } \\
\hline ADS & \multicolumn{5}{|c|}{ : aromatic betel leaf } \\
\hline
\end{tabular}

The higher the concentration of Arabic gum was, the thicker the form of the lotion would be. The highest form of viscosity level was obtained at $20 \%$ Arabic gum concentration, while the lowest one was obtained at $10 \%$ Arabic gum 
concentration. Arabic gum has a function as a suspending agent; thus, the more significant the use is, the thicker the liquid will be. The thickness produced from Arabic gum was caused by high molecular weight which was around 240,000 $580,000 \cdot{ }^{14}$

The Arabic gum structure (Figure 1) consists of complex polysaccharides and branched molecules with different mass variations. It contains amino acids and some sugar monomers, such as galactose and arabinose. ${ }^{14}$ The product had a white color, which had an aromatic odor of betel leaf as, in this formulation, essential oil of $2 \mathrm{ml}$ was added. This essential oil contained phenols, which caused lotion preparations to have an odor.

Meanwhile, formulas with CMC Na suspending agents (Figure 2) also produced different forms at each concentration. The highest viscosity was obtained at a concentration of $1 \%$, while the lowest one was obtained at a concentration of $0.25 \%$. Compared to Arabic gum, the lotion form with CMC Na suspending agent with the highest concentration produced a very coarse lotion form. It was due to the smaller molecular weight of Arabic gum, which was $90,000-700,000$, and the viscosity of liquid CMC Na. At higher concentrations, it can be used to prevent evaporation.

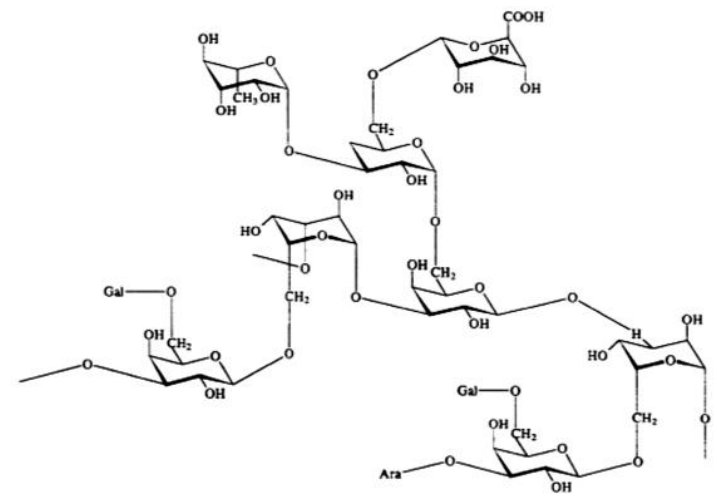

Figure1. The Chemical structure of Arabic gum

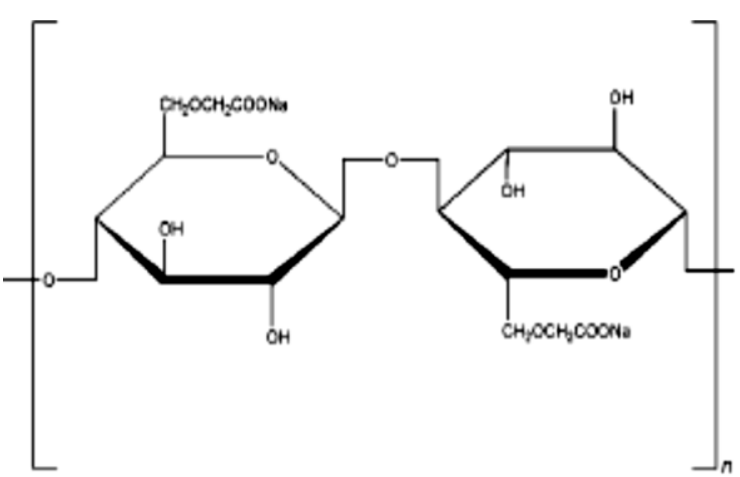

Figure 2. The Chemical structure of $C M C$ $\mathrm{Na}$

Based on the observations of $\mathrm{pH}$ obtained during the storage period, there was a change that the results obtained were close to the desired $\mathrm{pH}$ range. The $\mathrm{pH}$ requirement of betel leaf lotion, based on literature, was in the range of $5 \cdot 5 \cdot{ }^{17 \cdot}$. The $\mathrm{pH}$ values are shown in table 3 displayed variations in the betel leaf lotion concentration, which affected the length of time storage. It was because there was no addition of a buffer solution to the betel leaf lotion formulation. A buffer solution was a mixture of weak acids or bases with their conjugate acids or bases, which could maintain the $\mathrm{pH}$ around the buffer capacity area. The function of this solution as a buffer solution was to maintain the $\mathrm{pH}$.

The preparations on the market (Neutral Body Lotion) that had been measured had a pH of 5.5. It must be stable in the storage period as the preparations were not directly used. Similarly, betel leaf lotion preparations in this study were to be stable in mass storage.

The homogeneity test was conducted by applying $2 \times 2 \mathrm{~cm}$ of the lotion on a glass plate based on the concentration of each lotion. It was then touched and rubbed. The mass of the lotion showed how much the homogeneous distribution was on the glass plate. The six formulas can be seen in table 4, with the average smoothest- 
Table 3. pH Observation results

\begin{tabular}{lllllllllll}
\hline Formula & \multicolumn{10}{c}{ The average pH during storage time } \\
\cline { 2 - 11 } & $\mathbf{1}$ & $\mathbf{3}$ & $\mathbf{6}$ & $\mathbf{9}$ & $\mathbf{1 2}$ & $\mathbf{1 5}$ & $\mathbf{1 8}$ & $\mathbf{2 1}$ & $\mathbf{2 4}$ & $\mathbf{2 7}$ \\
\hline G1 & 4,75 & 4,72 & 5,36 & 4,76 & 4,61 & 4,63 & 4,65 & 4,63 & 4,61 & 4,61 \\
$\mathrm{G}_{2}$ & 4,74 & 4,75 & 4,65 & 4,68 & 4,63 & 4,66 & 4,69 & 4,66 & 4,68 & 4,62 \\
$\mathrm{G}_{3}$ & 4,73 & 4,61 & 4,59 & 4,56 & 4,56 & 4,71 & 4,63 & 4,55 & 4,58 & 4,55 \\
$\mathrm{C}_{1}$ & 6,72 & 6,44 & 6,51 & 6,05 & 5,84 & 5,82 & 5,76 & 5,77 & 5,67 & 5,65 \\
$\mathrm{C}_{2}$ & 6,63 & 6,45 & 6,43 & 6,08 & 5,93 & 5,94 & 5,87 & 5,86 & 5,77 & 5,75 \\
$\mathrm{C}_{3}$ & 6,90 & 6,78 & 6,82 & 6,55 & 6,35 & 6,38 & 6,31 & 6,30 & 6,17 & 6,16 \\
Comparison & & & & & 5,5 & & & & & \\
\hline
\end{tabular}

Table 4. The average of lotion homogeneity

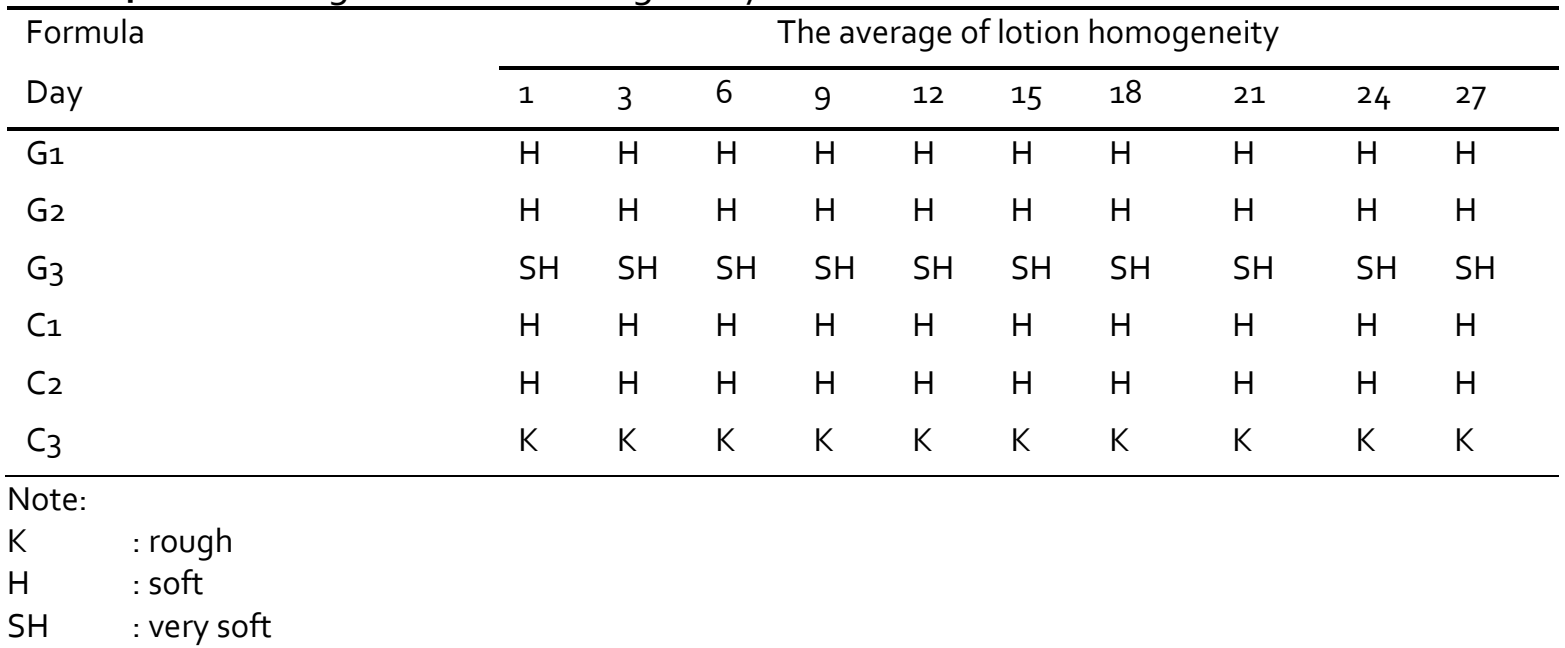

-homogeneity in formula G3. G3 was lotion using 20\% Arabic gum concentration. Whereas, the roughest homogeneity in the $C_{3}$ formula was lotion using $1 \%$ CMC $\mathrm{Na}$ concentration. The results of the study can be seen in Table 4 .

The lotion homogeneity test was carried out to find out whether the lotion was truly mixed after the mixing process. ${ }^{11}$ It was to ensure that the active substances contained therein have been distributed equally. Homogeneity was one of the factors that influenced the quality of the preparation of the lotion. Homogeneity affects the distribution of betel leaf extract active ingredients in the lotion. The active ingredients of betel leaf extract must be dispersed to provide maximum effectiveness as an antifungal.

An adhesion test is a test used to determine the maximum ability of the adhesive power of the lotion on the skin when it is used. The aim was to find out how strong the lotion preparations can be attached to the application area, such as the skin and to coat the surface of the skin in an impervious way, and not to clog pores and physiological functions of the skin. ${ }^{13}$ The adhesion test result was obtained by calculating the length of glass plates sticking or shifting that had been smeared with lotion. It was later overwritten with a load of $1 \mathrm{~kg}$ for 5 minutes and was released. The shift showed that the lotion was less attached 
Table 5.The results of the adhesion test

\begin{tabular}{|c|c|c|c|c|c|c|c|c|c|c|}
\hline \multirow{2}{*}{$\begin{array}{l}\text { Formula } \\
\text { Day }\end{array}$} & \multicolumn{10}{|c|}{ The average of the adhesion test in a minute } \\
\hline & 1 & 3 & 6 & 9 & 12 & 15 & 18 & 21 & 24 & 27 \\
\hline $\mathrm{G}_{1}$ & '33 & '38 & '27 & 46 & 34 & 29 & 28 & '27 & 29 & 28 \\
\hline $\mathrm{G}_{2}$ & '35 & '37 & 26 & '24 & 38 & 28 & 38 & 35 & 28 & 25 \\
\hline $\mathrm{G}_{3}$ & 52 & 38 & '27 & '24 & 50 & 47 & 37 & 34 & 30 & 31 \\
\hline $\mathrm{C}_{1}$ & 32 & '34 & 45 & 33 & 32 & 29 & 37 & 33 & 24 & '29 \\
\hline $\mathrm{C}_{2}$ & 1.63 & 7.34 & 140 & 1.88 & 49 & 142 & 36 & 31 & '33 & '34 \\
\hline$C_{3}$ & 1.32 & 2.27 & '25 & 39 & 36 & 38 & 26 & '24 & 38 & '39 \\
\hline
\end{tabular}

-to the applied skin area, and it was then smeared off. The results of the adhesion observation test can be seen in Table 5 .

The stickiness profile of each lotion was stored for four weeks after finding out that all lotion formulations had the same tendency. The longer the storage duration was, the more decreasing the time of the adhesion would be. The most significant decrease in the duration of the adhesive power of lotion was in formulas with $0.5 \%$ CMC-Na suspending agent and 1\% CMC$\mathrm{Na}$. Formula with Arabic gum suspending agent decreased the duration of adhesion compared to a formula with CMC-Na suspending agent.

\section{CONCLUSION}

Based on the physical quality test of lotion preparations that have been conducted, it can be concluded that the lotion preparations from betel leaf extracts with 20\% Arabic gum suspending agent had a physical quality that matched the required lotion dosage criteria.

\section{ACKNOWLEDGMENT}

The authors would like to thank the Universitas Muhammadiyah Yogyakarta for supporting this research.

\section{CONFLICT OF INTEREST}

The author declares that there is no conflict of interest.

\section{REFERENCES}

1. Dorland, W. N. (2012). Kamus saku kedokteran Dorland edisi 28. Jakarta: EGC.

2. Sahoo, A. K., \& Mahajan, R. (2016). Management of tinea corporis, tinea cruris, and tinea pedis: A comprehensive review. Indian dermatology online journal, $7(2)$, p. 77.

3. Wantini, S., Violita, Y., \& Sulistianingsih, E. (2017). Perbandingan Uji Efektivitas Air Perasan Lengkuas Merah (Alpinia purpurata K. Schum) Dengan Air Perasan Lengkuas Putih (Alpinia galnga L. Wild) Terhadap Pertumbuhan Jamur Malassezia furfur Penyebab Panu. Jurnal Analis Kesehatan, 2(2), pp. 282-289.

4. Ardelia, P. I., Andrini, F., \& Hamidy, M. Y. (2017). Aktivitas Antijamur Air Perasan Daun Seledri (Apium graveolens L.) Terhadap Candida albicans Secara In Vitro. Jurnal Ilmu Kedokteran, 4(2), pp. 102-107.

5. Hariyanto, S., 2012. Ensiklopedia Tanaman Obat Indonesia. Jakarta: Mitra Setia. 
6. Yuniarti, T, 2008. Ensiklopedia Tanaman Obat Tradisional. Yogyakarta: Media Presindo.

7. Erwiyani, A. R., Luhurningtyas, F.P., \& Sunnah, I. (2017). Optimasi formula sediaan krim ekstrak etanol daun alpukat (Persea americana Mill) dan daun sirih hijau (Piper betle Linn). Cendekia Journal of Pharmacy, 1(1), pp. 77-86.

8. Nurhidayati, L. Y. D., \& Mariani, S. (2012). Penetapan Kadar Eugenol dalam Minyak Atsiri dari Daun Sirih Merah ( Piper of fragile Benth.) dan Sirih Hijau ( Piper betle L.) secara Kromatografi Gas. In Seminar Nasional POKJANAS TOI XLII.

9. Octavia, M. D., Halim, A., \& Afrinda, M. (2017). Karakterisasi Kompleks Inklusi Simvastatin-B-Siklodekstrin Metoda Co-Grinding dengan Variasi Waktu Penggilingan. Jurnal Farmasi Higea, 7(1), pp. 30-43.

10. Anggraini, D., \& Kasmawati, L. Y. (2017). Formulasi Gel Sarang Burung Walet Putih (Aerodramus fushipagus) dan Uji Penyembuhan Luka Bakar Derajat II pada Mencit. Jurnal Sains Farmasi \& Klinis, 4(1), pp. 55-6o.

11. Fajriyah, U., Astuti, I. Y., \& Hartanti, D. (2010). Formulasi Losion Ekstrak Herba Tali Putri (Cuscuta Australis R. Br.) Dan Aktivitas Antioksidan Secara in Vitro. PHARMACY: Jurnal Farmasi Indonesia (Pharmaceutical Journal of Indonesia), 7(01), pp. 24-34.
12. Fitriana, A. Y., Wahyuningrum, R., \& Sudarso, S. (2012). Daya Repelan Dan Uji Iritasi Formula Lotion Ekstrak Etanol Daun Sirih (Piper Betle Linn) Dengan Variasi Basis Lanolin Terhadap Nyamuk Aedes Aegypti. PHARMACY: Jurnal Farmasi Indonesia (Pharmaceutical Journal of Indonesia), 9(02), pp. 39-57.

13. Siregar, C. J., \& Wikarsa, S. (2010). Teknologi Farmasi Sediaan Tablet Dasar-Dasar Praktis. Jakarta: EGC.

14. Rowe, R. C., Sheskey, P., \& Quinn, M. (2009). Handbook of pharmaceutical excipients. London: Libros DigitalesPharmaceutical Press.

15. Hadning, I., (2016). Formulasi dan uji stabilita fisik sediaan oral emulsi virgin coconut oil. Mutiara Medika: Jurnal Kedokteran dan Kesehatan, 11(2), pp. 88-100.

16. Nurlina, N., Tomagola, M. I., Hasyim, N., \& Rahman, F. (2014). Formulasi suspensi kering kombinasi ekstrak etanol kunyit (Curcuma longa L.) dan serbuk daging buah pisang kepok (Musa balbisiana Colla.) dengan variasi bahan pensuspensi. As-Syifaa Jurnal Farmasi, 6(2), pp. 166-177.

17. Yuliana, A., Nurdianti, L., Fitriani, F., \& Amin, S. (2020). Formulasi Dan Evaluasi Kosmetik Dekoratif Perona Pipi Dari Ekstrak Angkak (Monascus Purpureus) Sebagai Pewarna Dengan Menggunakan Lesitin Sebagai Pelembab Kulit. FITOFARMAKA: Jurnal Ilmiah Farmasi, 10(1), pp. 1-11. 